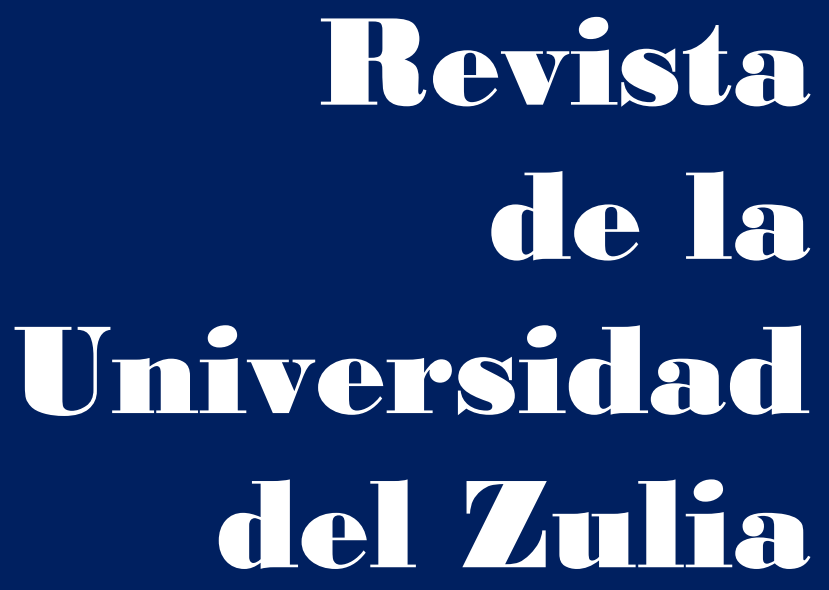

Fundada en 1947

por el Dr. Jesús Enrique Lossada

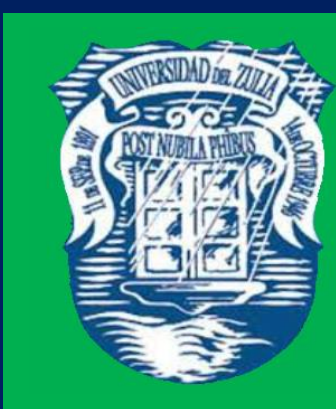

Ciencias del

Agred

Ingemieria

y Teenología
Añต 12 No 32

Enero - Abril 2021

Tercera Época

Maracailbo-Venezuela 


\title{
International experience on the improvement of national management technology and legal regulation of public contracts
}

\author{
Viktoriia Holubieva * \\ Liliia Nevara ** \\ Serhiy Savchuk *** \\ Andriy Detiuk **** \\ Valerii Tatsiienko*****
}

\begin{abstract}
The objective of the research is to study the global experience of the legal regulation and organization of public procurement (from a not only legal but also a technological perspective), which should be the basis for suggestions to improve the legal regulation mechanism for procurement public in Ukraine. For the implementation of the comparative legal part of the study, normative legal acts and acts of official interpretation of the legal systems of the following states, as well as related scientific and scientific-practical materials, were used: USA, Australia, New Zealand, Japan, Switzerland, South Korea, United Kingdom, Japan, Egypt, Canada, Malaysia, Israel, India, Argentina, Australia, New Zealand. The unification of electronic public procurements systems remains to be a topical and unresolved task for the WTO GPA member countries. The experience of some countries in encouraging small and medium-sized enterprises in electronic public procurement is considered progressive and positive. We consider it necessary to adopt the experience of the USA, Israel, China countries and accelerate the adoption of laws in Ukraine to support national producers.
\end{abstract}

KEYWORDS: international experience; legal regulation; public procurement; tender documentation; electronic database of public procurement.

*PhD in law, Associate Professor, Professor of International and European Department, Law Institute, Kyiv National Economic University named after Vadym Hetman, Ukraine. ID ORCID: https:/orcid.org/00000003-3903-345l.E-mail: holubievavic@i.ua

**PhD in Law, Associate Professor of International Law and Comparative Law Department, National Aviation University, Ukraine. ID ORCID: https:/orcid.org/0000-0003-1775-8806. E-mail: nevaralili@i.ua

***PhD in Law, Associate Professor of International Law and Comparative Law Department, National Aviation University, Ukraine. ID ORCID: https://orcid.org/0000-0002-1814-0509. E-mail: Savchuksergio@i.ua

****PhD in Law, Director, 'Crocus, LTD', Ukraine. ID ORCID: https://orcid.org/0000-0001-5344-5669. Email: detiukandriy@i.ua

*****PhD in Law, Associate Economic Security and Financial Investigations Department, National Academy of Internal Affairs, Ukraine. ID ORCID: https:/orcid.org/0000-0001-8127-457X. E-mail: tatsiyenkoval@i.ua

Recibido: 15/10/2020

Aceptado: 08/12/2020 


\section{Experiencia internacional en la mejora de la tecnología de gestión nacional y regulación legal de la contratación pública}

RESUMEN

El objetivo de la investigación es estudiar la experiencia global de la regulación legal y la organización de la contratación pública (desde una perspectiva no solo legal sino también tecnológica), que debe ser la base de sugerencias para mejorar el mecanismo de regulación legal de la contratación pública en Ucrania. Para la implementación de la parte jurídica comparada del estudio se utilizaron actos jurídicos normativos y actos de interpretación oficial de los sistemas jurídicos de los siguientes estados, así como materiales científicos y científico-prácticos relacionados: EE.UU., Australia, Nueva Zelanda, Japón, Suiza, Corea del Sur, Reino Unido, Japón, Egipto, Canadá, Malasia, Israel, India, Argentina, Australia, Nueva Zelanda. La unificación de los sistemas electrónicos de contratación pública sigue siendo una tarea de actualidad y sin resolver para los países miembros del ACP de la OMC. La experiencia de algunos países en el estímulo a las pequeñas y medianas empresas en la contratación pública electrónica se considera progresiva y positiva. Consideramos necesario adoptar la experiencia de los países de EE. UU., Israel, China y acelerar la adopción de leyes en Ucrania para apoyar a los productores nacionales.

PALABRAS CLAVE: experiencia internacional; regulacion legal; la contratación pública; documentación de la licitación; base de datos electrónica de contratación pública.

\section{Introduction}

In fact, the legislation of Ukraine related to the government procurement is continuously developing and systematising, but nonetheless, there are the existing and potential risks and problems of functioning, which are to be solved. That is, one of the significant problems of the government procurement system of Ukraine is the considerable scope and 'relative novelty' of the regulatory framework. Constant change of statutory instruments is one of the main problems of the system of state procurement, which leads to ambiguous interpretation of principles and rules of public procurement, as well as to ineffective enforcement. One may say that recently the legislation on government procurement has been drastically changing, which in practice leads to numerous conflicts and difficulties in practical activities of business entities.

It should separately be noted that Ukraine, as well as many other countries, relied on the UNCITRAL Model Law 'On Procurement of Goods, Construction and Services', dated 
REVISTA DE LA UNIVERSIDAD DEL ZULIA. 3ª época. Año 12 N 32, 2021

Viktoriia Holubieva et al. // International experience on the improvement of national ... 460-485

DOI: http://dx.doi.org/10.46925//rdluz.32.27

June 17, 1994 (UNCITRAL, 1994) when developing a national profile/special law in the field of government/public procurement. It is worth pointing that not all the countries have specific legislative acts regulating government/public procurement, but are guided by the subordinate legislation (for example, Australia (Australian Government, n.d.), New Zealand (New Zealand, n.d.; GETS.GOVT.NZ, n.d.; BUSINESS.GOVT.NZ, 2020).

\section{Purpose and Objectives of the Study}

The objective of the research is to study the global experience of the legal regulation and organization of public procurement (from a not only legal but also a technological perspective), which should be the basis for suggestions to improve the legal regulation mechanism for procurement public in Ukraine. Identified advanced ideas, progressive practices, and autho's suggestions can be a scientific product that is suitable for its use by scientists and practitioners in other countries.

Let us consider some provisions of the Law of Ukraine 'On Public Procurement' in comparison with the WTO GPA, relevant regulations of the Association Agreement, national practice and foreign experience (best practice), taking into account some aspects of the process of government procurement. In particular (Nabiullin \& Kuznetsova, 2012: 16 17): a) the efficiency of meeting state (whole-of-government and municipal) needs for goods, works, and services in full, acceptability of terms and the best ratio of quality and price; b) the competition due to the maximum number of participants/suppliers, transparency of all stages of the procurement procedures and information provision, which, in its turn, should counteract corruption when applying the mechanism of government/public procurement; c) the promotion of the development of a national commodity producer (especially small and medium sized enterprises).

\section{Methods and Materials}

The methodological basis of the research is formed by a complex of general scientific, special-scientific methods of cognition, including dialectical, systemic, structuralfunctional, hermeneutic, comparative-legal, formal-legal (dogmatic), modeling method.

The dialectical method helped to identify legal and factual contradictions about the type of legal regulation of public procurement in Ukraine. The structural-functional method showed the advantages and prospects of creating a special authority for regulating 
REVISTA DE LA UNIVERSIDAD DEL ZULIA. 3ª época. Año 12 N 32, 2021

Viktoriia Holubieva et al. // International experience on the improvement of national ... 460-485

DOI: http://dx.doi.org/10.46925//rdluz.32.27

public procurement, and also showed the feasibility of creating subject catalogs for the electronic database of public procurement. The subject of a synchronous legal comparison in the paper was the existing organizational and legal mechanisms for regulating public procurement in different countries. At the same time, mainly legal norms and institutions of different countries were subjected to microcomparison. These methods represent the empirical part of the study, based on the study of legal texts related, first of all, to the number of sources of law.

At the same time, the empirical part of the research is preceded by a rational component, which involves the use of a general scientific method of deduction, used to reconstruct hypothetical ideas necessary to achieve the purpose of the research. This method made it possible to identify both the general, which is the same in the procedures for conducting public procurement in different countries, and the particular, noncoincident. The cognitive value of this method consisted in identifying general patterns of development of the institution of public procurement in different countries, the knowledge of which serves as a prerequisite for proposals for improving national legislation. The method of legal modeling made it possible to formulate regulatory provisions as drafts of legal norms to supplement laws.

Source base of the study. The source base of the study was made up of the works of Ukrainian and foreign researchers, as well as legal texts related to various legal systems, and doctrinal generalizations of legislation, practices necessary for the implementation of tasks related to the application of the comparative legal method in the study. For the implementation of the comparative legal part of the study, normative legal acts and acts of official interpretation of the legal systems of the following states, as well as related scientific and scientific-practical materials, were used: USA, Australia, New Zealand, Japan, Switzerland, South Korea, United Kingdom, Japan, Egypt, Canada, Malaysia, Israel, India, Argentina, Australia, New Zealand, et al.

3. Results and Discussion

3.l. Types of implementing and regulating government procurement in a world practice 
REVISTA DE LA UNIVERSIDAD DEL ZULIA. 3ª época. Año 12 N 32, 2021

Viktoriia Holubieva et al. // International experience on the improvement of national ... 460-485

DOI: http://dx.doi.org/10.46925//rdluz.32.27

In the world, three types of implementing and regulating government procurement are conventionally used: centralized (USA), decentralized (Australia, New Zealand, Japan, Switzerland) and combined (South Korea, United Kingdom). Ukraine, declaring the centralized method (Article 1 par 36 of the Law of Ukraine No.922-VIII), basically applies the combined one in practice. The current trend in the world is to reduce the number of decentralized purchases, that is, carrying out them by state authorities independently, and to implement the system, in which procurement for government needs will be carried out, as a rule, centrally (Nabiullin $\&$ Kuznetsova: 17). One of the most difficult problems is the introduction of a centralised procuring organisation in Ukraine, on the model of the EU countries, which is enshrined in the Law of Ukraine No.922-VIII and in the Resolution of the Cabinet of Ministers of Ukraine On Launching the Pilot Project for Central Procurement Organization Activity Arrangement, dated Nov. 23, 2016.

In accordance with the Law of Ukraine No.922-VIII, all budgetary and state institutions began to purchase for more than the amount determined (as a rule, UAH 200.000 for procurement of goods and services and UAH 1.5 million for procurement of works (Article 2 par. 1)), on the basis of 'ProZorro' electronic platform.

The Ministry of Economic Development and Trade of Ukraine (par. 1) (CMU, 2014) was determined as the authorized body in the field of government/public procurement (Article 1 par. 34; Article 8 par. 1, 2), while the Anti-Monopoly Committee of Ukraine is the appeal body in this field (Article 1 par. 14; Article 8 par. 3), which corresponds to the obligations of our State under Article 150 par. 2 (a), (b) of the Association Agreement 2014. That is, Ukraine does not have a specially created central government body, which not only regulates/coordinates (as well as the Ministry of Economic Development and Trade of Ukraine), but directly carries out public procurement in a countrywide scale, for example, as in case with:

- the Republic of Korea: the Public Procurement Service (PPS), which, among other things, manages and maintains the Korea ON-line E-Procurement System (KONEPS) that provides access to government procurement for all interested parties on a single official web-site in real time via the Internet ('ProZorro' Electronic System operates in a similar way in Ukraine). KONEPS can be an example of the further development of ProZorro, as one of the most advanced systems. For example, more than 160 forms of documents for the 
REVISTA DE LA UNIVERSIDAD DEL ZULIA. 3ª época. Año 12 N 32, 2021

Viktoriia Holubieva et al. // International experience on the improvement of national ... 460-485

DOI: http://dx.doi.org/10.46925//rdluz.32.27

electronic document circulation were 'sewed', and Government for Citizens (G4C) data exchange system was integrated into KONEPS system, which allows to reduce the number of and, in general, avoid hard copies from participants in /suppliers of bidding, etc.;

- the USA: the Office of Federal Procurement Police. The main information resource for suppliers is the Federal Business Opportunities Portal (FPDS, n.d.), which contains the information about customers, suppliers, and the reference information. (By the way, the organizational and legal provision of government procurement in Canada is carried out according to the similar scheme by the Public Works and Government Services Canada (Buyandsell.gc.ca, n.d.) through the system of its main public portal). The Federal Government Procurement Information System in the USA is quite complex, and contains at least nine resources (open, closed, auxiliary, etc.), which have been integrated into the System for Award Management (SAM) since 2014, in order to unify and simplify the registration for access and enhancement of functionalities, avoidance of the duplication of information, etc. One cannot ignore mutual similar allegations of lack of transparency on the part of the EU against the United States: 'Lack of transparency: It is not easy to find proper and timely information on government contracts opportunities in the US. There is no general access point (apart from the Federal tenders) to information on opportunities to bid for government contracts and the information is provided is often unclear' (EU, 2019a).

- Japan: the Japan External Trade Organization (JETRO, n.d).

As a result of the study of existing approaches to government/public procurement, several of its models have been formed: a) the American Model based mainly on the single national strategy for the budget allocation, and the determination of a structure of government orders and the procedure for their receipt; b) the European (Continental) Model based on the competitive placement of public funds, and their contractual distribution in the procurement process.

3.2. Information systems and internet technologies as means of national management technology of public procurement

In the academic literature, the term 'technology` is considered as a set of forms, methods and techniques of any process aimed at achieving goals (Ivanov \& Patrushev, 1995: 222). Technology refers to methods, systems, and devices which are the result of scientific knowledge being used for practical purposes (Collins Dictionary, n.d). It follows that 
REVISTA DE LA UNIVERSIDAD DEL ZULIA. 3ª época. Año 12 N 32, 2021

Viktoriia Holubieva et al. // International experience on the improvement of national ... 460-485

DOI: http://dx.doi.org/10.46925//rdluz.32.27

management technology is a set of forms, methods, means of influencing the subject of management on the object of management in order to achieve a better result (Ivanov \& Patrushev, 1995: 222).

In our study, the term 'technology` should be used in two senses: first, as a special set of forms, methods, ways and means of national management of the public procurement system; secondly, as information, hardware, development, software products. In the first case, the term 'technology' forms the concept of 'national governance (management) technology', and in the second case - forms the concept of 'information technology`.

According to Hrihorii Atamanchuk, "modern technologies are systems: goals procedures (rules) - technical means - operations (actions) - motives (incentives)" (2006). H. Atamanchuk, V. Ivanov \& V. Patrushev expresses their essence in this way:

1) unswerving, mandatory and systematic implementation of established procedures and actions, as a result of which the desired (planned) objective result (product, product) in the specified parameters should always occur;

2) mass, large-scale and widespread use the most rational and effective procedures and operations for the production of certain products and social services (consumer values);

3) the use of those procedures and operations, technical means and forms of behavior that are among the latest achievements, correspond to the world level and bring maximum social effect` (2001; 2006: 32).

Public administration technologies as a set of techniques and procedures for purposeful activity not only streamline the means to achieve the goal, but also consolidate the sequence of actions, the development of appropriate algorithms for the subject's behavior. It is the algorithms that isolate and consolidate the most optimal and effective ways to solve a particular problem, and also make it possible to transfer and replicate the acquired experience.

The structure of public administration technologies, as a rule, includes three most significant components: specific knowledge; specific techniques, procedures and methods of action; as well as various technical and resource components. 
REVISTA DE LA UNIVERSIDAD DEL ZULIA. 3ª época. Año 12 N 32, 2021

Viktoriia Holubieva et al. // International experience on the improvement of national ... 460-485

DOI: http://dx.doi.org/10.46925//rdluz.32.27

Specific techniques and methods of activity of public administration bodies directly depend on the availability of certain personnel structures, technical equipment, and the availability of resources that affect the content of public administration technologies.

Re-organising public administration with extensive use of new technologies and an emphasis on e-Government initiatives and schemes has become a priority for the government in power, with the aim of a more costeffective, and open public administration (EPLO, n.d.: 3).

By integrating the use of Information and Communication Technologies (ICTs) in its procedures, public administration can achieve an increase in productivity and efficiency and, simultaneously, reduce phenomena of corruption and maladministration (EPLO, n.d.: 7).

The use of new technologies in administrative procedures not only renders 'red-tape' obsolete, but above all implies a major reshaping of the public administration-citizen relation, opening up administrative action to citizens.

A permanent virtual channel is built to permit interaction between the public administration and the individual. The individual citizen is progressively transformed from 'administered' person to an interlocutor on equal terms with the public administration (EPLO, n.d.: 12).

An important innovation in the public procurement system was the phenomenon of digitalization, introduced into this area by creating a national information platform (space).

Thus, the combination of modern methods and technologies of digitalization makes it possible to significantly automate the process of public procurement and their management, to reduce the corruption and bureaucratic components of the contract system, to optimize the time of operations performed while observing the current trends in digitalization of all areas of activity.

One of the methods to implement the principle of transparency is the online-access to the information (first of all, official one) about conditions of government procurement, and even just to the regulatory legal framework on this issue (Alians Media, n.d.). In the vast majority of countries, there is a clear tendency to the growth in the number of government procurement, precisely using the information provision and automation. As already noted, 'ProZorro' System is unique not only for Ukraine, but also for the world. The 
REVISTA DE LA UNIVERSIDAD DEL ZULIA. 3ª época. Año 12 N 32, 2021

Viktoriia Holubieva et al. // International experience on the improvement of national ... 460-485

DOI: http://dx.doi.org/10.46925//rdluz.32.27

System allows the online monitoring of all purchases (for example, for the years 2019-2020: - 3.93 million tenders (QlikTech International AB, 2020) took place) for the entire period of its existence from time of the invitation for tenders until signing and completion of a contract thereunder. Each day, this quantity increases by an average of 4-5 thousand procedures. The total procurement budget (the value of signed contracts), announced in 'ProZorro' System for the entire period of its existence, already amounts to UAH 292.4 billion (Zakupki.Prom.ua, 2020).

Inter alia, Ukraine can 'get a look' at the foreign experience of creating and maintaining various electronic databases and catalogues of the narrow focus, within the framework of 'ProZorro' System or outside it.

Electronic systems also ensure the avoidance of the direct contact between officials and potential suppliers, which should help to 'mitigate the risks of corruption' and promote the standardization of government/public procurement processes.

In order to further simplify and universalize public procurement, it is necessary to seek technical solutions for ensuring the interconnection among relevant national electronic systems, at first instance, the WTO GPA contracting countries. For example, these are the Ukrainian ProZorro System, the European information procurement system 'Tender Electronics Daily' (TED, 2020), the American System for Award Management (SAM), the South Korean KONEPS, the Israeli one with the main web-portal for government procurement (in Hebrew) (Israeli Government Procurement Administration, 2020) and several other government sites that contain the information about tenders (ISRAEL NATURAL GAS LINES LTD, 2020; NTA, 2020), etc.

In accordance with the international obligations and national legislation, companies from the States - Parties to the WTO GPA and the EU Member-Countries have the full access to the Ukrainian market of government procurement (although in practice, the use of this right is complicated by various technical difficulties, which make it easier for foreign business to participate in procurement through subsidiaries registered in Ukraine) (EUUkraine, 2019: 42). By the way, sometimes, companies in Switzerland registered in different cantons face, for example, the similar problem and its solution in government procurement.

In accordance with Article 1:35 of the Law of Ukraine No.922-VIII, a participant in the government procurement procedure may be an individual, including an individual- 
REVISTA DE LA UNIVERSIDAD DEL ZULIA. 3ª época. Año 12 N 32, 2021

Viktoriia Holubieva et al. // International experience on the improvement of national ... 460-485

DOI: http://dx.doi.org/10.46925//rdluz.32.27

entrepreneur, or a legal entity (resident or non-resident), who submitted a tender offer, or took part in negotiations in case of applying the negotiable procurement procedure. That is, Ukraine does not restrict the access of foreign entities from any countries to the public procurement market, since it provides/applies the principle of non-discrimination; on the other hand, domestic enterprises de jure also get access to some foreign markets, but so far they cannot properly compete on them (Articles 3, 5, 12 of the Law of Ukraine No.922VIII). Also, by comparison, it should be noted that in the USA, since January 2018, the threshold for the participation of foreign companies in government procurement was raised from USD 150.000 up to USD 250.000 (EU, 2019a).

The most part of countries across the world, especially the advanced ones, cares for the existence and development of various types and forms of economic activities, in particular, small and medium sized enterprises, including the possibility of their involvement in government procurement. The latter is usually done by facilitating the access of small and medium sized enterprises to government procurement.

Unfortunately, the attention is not separately focused on this issue anywhere in Ukraine, as opposed to other States. For example, in Egypt 'In the 2004 Small and Medium Sized Enterprises (SMEs) Development Law, Egyptian SMEs were given the right to supply 10 percent of the goods and services in every government procurement contract' (USA, 2017: 125). India, which is an observer to the WTO GPA, paves this same path: 'The government also provides preferences to Indian micro, small, and medium enterprises and to state owned enterprises. Moreover, India's defense offsets program requires companies to invest 30 percent or more of the acquisition cost of contracts above the threshold value in Indian produced parts, equipment, or services' (USA, 2017: 209). The USA also has a 'US SME preference policy, which reserves about $23 \%$ of the value of US government contracts to US SMEs' (EU, 2019a). In the Republic of Korea, one of the key features of KONEPS is the system of the so-called On-line Shopping Mall, which contains the lists of goods and small and medium sized enterprises, as well as Handbook of Excellent Products, which includes the products of significant enterprises that have some difficulties in supplying goods and services for government needs in some areas (for example, medicine and construction, scientific, electronic and electrical equipment, etc.) (Something remotely similar is set out in Article 1:4 of the Law of Ukraine No.922-VIII: 'activities in certain areas of the economic 
REVISTA DE LA UNIVERSIDAD DEL ZULIA. 3ª época. Año 12 N 32, 2021

Viktoriia Holubieva et al. // International experience on the improvement of national ... 460-485

DOI: http://dx.doi.org/10.46925//rdluz.32.27

management'). In order to get into 'Handbook of Excellent Products', the Commission quarterly conducts the examination, based on the results of which the status of a 'state supplier' can be awarded for three years that enables customers to directly enter into government contracts. With the view of understanding the main principles of government procurement and implementing 'Sales of the Government of Canada', the 5-step approach is applicable in this country to help small businesses (Buyandsell.gc.ca. (n.d., b).

Although, in the EU regulatory acts, there is no word about discrimination of foreign participants in government procurement, but: 'The directive on procurement procedures in the utilities sector covers purchases in the water, transportation, energy, and postal sectors. This directive requires open and competitive bidding procedures, but it permits Member States to reject bids with less than 50 percent EU content for tenders that are not covered by an international or reciprocal bilateral agreement. The EU content requirement applies to foreign suppliers of goods and services in water (the production, transport, and distribution of drinking water); energy (gas and heat); urban transport (urban rail, automated systems, trams, buses, etc.); and postal services. Subsidiaries of U.S. companies may bid on all public procurement contracts covered by the EU Directives.' (USA, 2017: 173). In addition, some of the EU countries have national barriers in the area of government procurement, for example: France prefers its national commodity producers, even at worse competitive rates for their products; in Poland, the compliance with the government procurement requirements is too complicated for foreign companies; in Italy, there are complaints about corruption in this area (USA, 2017: 174-175) (by the way, the same thing as in Ukraine (OECD, 2015; OECD, 2017), etc.

Moreover, for example, Malaysia is an observer to the WTO GPA, but is not yet a signatory. Malaysia has traditionally used government procurement contracts to support national public policy objectives, including encouraging greater participation of bumiputera (the majority Malay ethic group) in the economy, transferring technology to local industries, reducing the outflow of foreign exchange, creating opportunities for local companies in the services sector, and enhancing Malaysia's export capabilities (USA, 2017: 300). In order to strengthen the role of a national commodity producer in government procurement, in 2009, Australia (a signatory of the WTO GPA) has implemented the project 'Enhancing the participation of the Australian Industry', and in 2011, has adopted 
REVISTA DE LA UNIVERSIDAD DEL ZULIA. 3ª época. Año 12 N 32, 2021

Viktoriia Holubieva et al. // International experience on the improvement of national ... 460-485

DOI: http://dx.doi.org/10.46925//rdluz.32.27

the Law 'Buy Australian Home and Abroad'. Furthermore, in 2015, the 'rule of indigenous peoples' was brought into force, according to which 3\% of winners in public procurement should be 'companies of indigenous peoples'.

\subsection{Public-private partnership in a public procurement process}

The public-private partnership cannot be overlooked as a form of cooperation between state authorities and business entities that are being established to ensure the implementation of infrastructure projects, or to provide services to the public. These forms of the partnership exist in some industries of the public sector, such as: transport, health care, education, public safety, waste and water supply management (Pappas, 2005: 45; Pyvovar et al., 2019). For example, in Canada, 'Hydro-Quibec, a provincial-level Crown Corporation in Quebec, maintains a local (Quebec) content requirement in its procurements for wind energy projects, and these local content requirements can pose hurdles for U.S. companies in the renewable energy sector in Canada' (USA, 2017: 69). On the other hand, in the USA, 'Buy America type of provisions have become a regular feature of bills funding Federal grants to the states, municipal or transit authorities. Restrictions have also extended to areas outside of transportation, such as environmental infrastructure projects. The Water Resources Reform and Development Act (WRRDA) adopted in 2014, which imposed new and permanent Buy America restrictions on procurements funded by the Environmental Protection Agency's (EPA) Clean Water infrastructure fund' (EU, 2019a). A positive example of the public-private partnership in Ukraine is the project of the street lighting modernization in Kyiv.

3.4. Subject composition of public procurement in the legislation of Ukraine and foreign countries

Certainly, the sovereign right of each state is to independently (taking into account the international commitments made, geopolitical and economic aspirations, national foreign and internal policies, social needs, etc.) determine, how to spend public funds, namely: what to buy, from whom to buy and according to which procedure, etc. Quite often, the attempts by countries to define and enshrine priorities, based on the legal framework, in relation to the objective (what to buy) and subjective (from whom to buy) 
REVISTA DE LA UNIVERSIDAD DEL ZULIA. 3ª época. Año 12 N 32, 2021

Viktoriia Holubieva et al. // International experience on the improvement of national ... 460-485

DOI: http://dx.doi.org/10.46925//rdluz.32.27

composition of government/public procurement, are considered as a violation of the freedom of competition, or manifestations of protectionism or lobbying.

In accordance with the legislation of Ukraine (Article 16 par.18 of the Law of Ukraine No.922-VIII), the subject of the government/public procurement procedure may be 'goods, works or services purchased by the customer within the single procurement procedure, in respect of which participants are allowed to submit tender offers, or proposals at negotiations (in the event of applying the negotiable procurement procedure)'.

The EU experience (as the internal market covering 28 states of the world) is interesting in generalization of the conceptual and objective compositions of government/public procurement in the Common Procurement Vocabulary (CPV), which is a nomenclature established by the EU Commission Regulation No. 213/2008 (EU, 2007), for the systematization and classification of goods and services as subjects of government procurement contracts, as well as facilitation of the search for relevant tender offers in the EU single procurement system: Tenders Electronic Daily (TED). The TED consists of a basic vocabulary for defining the subject of a contract, and an additional vocabulary for adding further qualitative information (EU, 2019b). In general, besides, it is still possible to define the product code according to the UN documents (UN, 2019), for the USA and Canada - under NAICS (NAICS Association, 2018), etc.

Ukraine needs to more actively use the international and domestic, organizational and legal (protectionistic) instruments for the protection of national economic interests and interests of national commodity producers and commodity consumers on the government/public procurement market. (Although, it causes, as a rule, a negative reaction from the part of foreign partners/competitors that even see a violation by Ukraine of its obligations under the GPA and Association Agreement (EU-Ukraine, 2019: 42)). For example, in December 2017, the Verkhovna Rada of Ukraine approved the first reading of a draft law 'Buy Ukrainian', which stipulates preferences in government/public procurement for goods manufactured in Ukraine (VRU, 2017). It is exactly in this issue that the experience of the USA and Israel (since all states are parties to the WTO GPA) is developmental for Ukraine.

The US Law 1933 'Buy America Act', and its variations 'Buy American' at the level of the separate States, and the Executive Order, dated April 18, 2017 on 'Buy American and 
REVISTA DE LA UNIVERSIDAD DEL ZULIA. 3ª época. Año 12 N 32, 2021

Viktoriia Holubieva et al. // International experience on the improvement of national ... 460-485

DOI: http://dx.doi.org/10.46925//rdluz.32.27

Hire American' are considered by other countries or regional economic integrations (like the EU) to be discriminatory, given the fact that they envisage 'to require use of American and local goods, services, suppliers and service providers or at least give them special favourable consideration' (EU, 2019a). In addition to this, the practice of various types of 'state preferences' is actively used, namely: a) the price preference from 5\% up to $15 \%$ for national companies; b) reciprocal preferences are applied against out-of-state bidders when their jurisdiction of origin applies preferences against out-of-state bidders; c) tie bid preference - when two bidders propose the same price for the same contract, the in-state bidder will be favoured (this is not always codified, for example, Kentucky has an informal tie bid preference; d) specific product preferences are most often agricultural products, including fisheries, steel, and printing products and services which must be procured from within the state unless unavailable (Canada, 2015). The similar practice is applied in the EU countries, and in Israel. In China, it is legally allowed to buy national goods and services only for budgetary funds, except for those that are 20\% more expensive than the imported ones.

The States may support separate producers or goods, or industries of production. One of the most stimulated industries in the world is agriculture / the agro-industrial complex. For example, in the USA, the target fixed 'support prices' are set to guarantee the minimal income level for national farms (especially, in the States with the high unemployment rate); after government procurement, agricultural products are already sold by the State at the market prices (no matter how they are) (Pokrovskaya \& Uskova, 2008: 33). In the EU countries, the practice of 'state-guaranteed prices', which provide farmers with a certain level of income and affect export subsidies, prices for similar imported goods, etc., is applied (Pokrovskaya \& Uskova, 2008: 34). Also, as a rule, government procurement to support the defence capabilities of states is highly protected and priority-oriented; in particular, the USA has a list of product types that cannot be procured from foreign suppliers (Pokrovskaya \& Uskova, 2008: 35).

Israel also applies the price preference at the rate of up to $15 \%$ in favor of national suppliers (subject to the share of domestic suppliers in a tender of at least $35 \%$ ) for all international tenders (with the exception of tenders fallen within the scope of the WTO GPA). By the way, the restrictive measures similar to the 'price preferences' policy of the 
REVISTA DE LA UNIVERSIDAD DEL ZULIA. 3ª época. Año 12 N 32, 2021

Viktoriia Holubieva et al. // International experience on the improvement of national ... 460-485

DOI: http://dx.doi.org/10.46925//rdluz.32.27

USA and Israel are applied, for example, by: China, Japan, India, Brazil, Turkey, and Kuwait.

Israel has offset requirements that it implements through international cooperation agreements. Under international cooperation agreements, foreign companies that have been awarded government contracts are required to offset foreign goods or services provided under the contracts by agreeing to localization commitments that require one of the following: investment in local industry; co-development or co-production with local companies; subcontracting to local companies; or purchasing from Israeli industry. Since January 1, 2009, the IC offset percentage for procurements covered by Israel's GPA obligations has been 20 percent of the value of the contract; for procurements excluded from GPA coverage, the offset is 35 percent; and for military procurements the offset is 50 percent. Under the revised GPA, which entered into force in 2014, Israel committed to phase out its offsets on procurement covered by the agreement (USA, 2017: 240).

Argentina is not a signatory to the GPA, but it is an observer to the WTO Committee on Government Procurement. On November 16, 2016 the government passed a privatepublic partnership law (No. 27, 328), the law contains a 'Buy Argentina' clause which mandates at least 33 percent local content for every public project (USA, 2017: 31).

\subsection{Specifics of planning public procurement}

It should be noted that the Law of Ukraine 'On Public Procurement' does not refer, in general, to the planning for meeting the state needs; the question is only the allocation, use, and control over public funds (we must specify that the budget planning is regulated in Ukraine separately). Taking into account the OECD recommendations (the Third OECD Public Procurement Principle, where governments should guarantee that public funds have been used according to their intended purpose (OECD, 2009: 11)), and on the model of the USA (AAP - Advance Acquisition Program), it is more appropriate to integrate public procurement into the budget process by drawing up both a previous one-year procurement plan and a multi-year one (government-wide and sectoral), and to regulate such actions on the basis of the legal framework. The said actions should include the assessment of needs for budgetary funds for government/public procurement, justification of sources of their origin and drawing up a timetable for their allocation (uniform one according to 
REVISTA DE LA UNIVERSIDAD DEL ZULIA. 3ª época. Año 12 N 32, 2021

Viktoriia Holubieva et al. // International experience on the improvement of national ... 460-485

DOI: http://dx.doi.org/10.46925//rdluz.32.27

current/calendar needs, or emergency one due to unforeseen circumstances and urgent needs, for a calendar year and for a longer period). In other words, it is better to use the socalled 'single planning cycle’.

For example, in Canada, the vast majority of governmental authorities publishes annual procurement plans (such as, the Public Services and Procurement Canada, the Royal Canadian Mounted Police, etc.). On the other hand, the system of the unified budget accounting (dBrain) of the Republic of Korea is interesting, which allows the customer to pay for government contracts directly through the electronic portal, and to a supplier - to make provision for an application, and then to control over the circulation of budgetary funds using the audit/post-audit method, etc.

One of the problems of allocating public funds is the complexity, systematicity and completeness of the information about their necessity, incoming and spending, as well as the appropriate coordination and coherence of actions. In particular, it is quite difficult to predict and ensure the uniformity of budget (general and local) receipts in Ukraine; accordingly, it is difficult to plan their expenditures (government procurement). As a result, unfortunately: at the end of the fiscal year, there is a negative phenomenon, such as an urgent 'application' of budgetary funds; or the State does not generally fulfill its obligations under contracts concluded in a timely manner; if projects are long-term (in particular, design and construction), then one can wait a long while for financing of their next stage, etc.

Article 12 of the Law of Ukraine No.922-VIII provides for four types of the procurement procedures: open bidding (Section IV of Articles 20-33), competitive dialogue (Section V of Articles 34-35), procedure of restricted tendering (Section VI of Articles 3639), and negotiation procedure (Section VII of Article 40). In Article 10 par 3, it is enshrined that in the event of excess of the cost of the expected order (at the NBU rate as of the date of the public declaration of an invitation), for goods and services in amount of EUR 133.000, and for works - in amount of EUR 5.150.000, the additional declaration of an invitation in English shall be mandatory. The question arises of whether it is: a formal requirement to respect the principle of transparency; or - a separate procurement procedure; or - a threshold for the participation of foreign entities in government procurement? Based on the 
REVISTA DE LA UNIVERSIDAD DEL ZULIA. 3ª época. Año 12 N 32, 2021

Viktoriia Holubieva et al. // International experience on the improvement of national ... 460-485

DOI: http://dx.doi.org/10.46925//rdluz.32.27

explanations of the Ministry of Economic Development and Trade of Ukraine, it can be concluded that the question is just the type of the public procurement procedure.

Perhaps, it would be expedient to distinguish the type or subtype of an 'open bidding with publication in English', since the Law of Ukraine No.922-VIII has already stipulated the features associated with this: just the additional publication (Article 10 par. 4); the longer term (not 15, but not less than 30 calendar days) for submitting tender offers (Article 10 par.l, Article 21 par. 3); the additional prequalification period (another procedure for the consideration and evaluation of tender offers) (Article 27 par. 1:1, Article 28 par. 1, 5). However, the Law of Ukraine No.922-VIII did not envisage the tender documentation in English or its translation.

For example, the US Federal Acquisition Regulation (FAR) prescribes the following types of government procurement: open bidding; two-stage bidding; negotiation procedure; simplified procurement methods; procurement in the field of national defence and security, to which, in addition to the general regulation, the Defense Federal Acquisition Regulation - Supplement (DFARS) is also applicable. The formation and placement of government orders are carried out by the United States in two directions: for the current provision of the State's functioning, in accordance with the needs of either government/budgetary institutions; capital investments. In Israel, there is an even more detailed procedure of public procurement by types: public/open bidding; limited public bidding; selective bidding; exemption from the bidding procedure. Apart from that, in government tenders arranged for large projects, in respect of which the Israeli customer is interested in attracting foreign companies, there are several options for its conduct, in particular: an open international bidding that involves the cooperation of a foreign manufacturer with a local company, or the use of local subcontractors; a closed international bidding, which takes place after the open or closed procedure of the preliminary qualification; an open or a closed national tender, which envisages the cooperation of primary suppliers of Israeli origin with foreign companies.

Summarizing the procedure for government/public procurement stipulated in the Law of Ukraine No.922-VIII (first of all, the open one (Section IV of Articles 20-32)), the following stages/steps/phases can be noted: 
REVISTA DE LA UNIVERSIDAD DEL ZULIA. 3ª época. Año 12 N 32, 2021

Viktoriia Holubieva et al. // International experience on the improvement of national ... 460-485

DOI: http://dx.doi.org/10.46925//rdluz.32.27

1) organization and conduct of government/public procurement: planning and invitation to procurement, period of clarification and submission of offers; consideration of offers (prequalification); evaluation (auction); definition of a winner; conclusion of a procurement contract; report on the performance of a contract;

2) fulfillment of the terms and conditions of a government/public procurement contract by a supplier/contractor, and acceptance/rejection of its results by the customer;

3) control and supervision over the area of government/public procurement, in general, specific procedures and contracts, as well as their consequences on a short-and long-term horizon.

As in the study, each type of the procurement procedures will not be considered in detail, we note that the negotiation (actually non-competitive) procedure (Section VI of Article 35 of the Law of Ukraine No.922-VIII), namely the conditions for its implementation, does not materially meet the requirements of the Directive 2014/24/EU on government procurement. (For example, regarding: its exclusiveness, absence of competition, requirements for the publication of the tender documentation, possibility of applying the general or special procedures for conducting and their terms, etc.).

Alongside this, the extremely important issue, in particular for Ukraine, in the field of government procurement, is the possibility of the deeper resolution of urgent and emergency (with the significant current/short-term deterioration of the state or consequences) problems of the social and public nature. (For example: purchase of medicines or payment for the treatment as a result of accidents, catastrophes, etc.; urgent actions to overcome consequences of the exhaustive list of force major circumstances, or similar circumstances (in particular, demolition of bridges and roads by flood, consequences of hurricanes and hail stones, explosions/fire at military warehouses, accidents on heating networks in the winter period, etc.); holding of extraordinary elections, in particular those of a president, due to inconsistencies of terms in various regulatory acts, etc.). It would rather to systematically agree upon regulatory legal acts (first of all, about the timing for carrying out these or those actions) between themselves, than to contextually solve problems arisen (not always transparently and predictably, even with the 'justified' violations). 
REVISTA DE LA UNIVERSIDAD DEL ZULIA. 3ª época. Año 12 N 32, 2021

Viktoriia Holubieva et al. // International experience on the improvement of national ... 460-485

DOI: http://dx.doi.org/10.46925//rdluz.32.27

The certain interest can be caused by the rules for allocating funds of the World Bank, as set out in the Guide for Procurement under the IBRD Loans and IDA Credits (IBRD, 1995), which envisages the following types of procurement: International Competitive Bidding; National Competitive Bidding; Limited International Bidding; quotation request (Shopping); purchases from a single source (Direct Contracting).

For Ukraine, as well as for many countries of the world, the issue of avoiding the international and domestic (imperative and dispositive) regulations in the process of government/public procurement is relevant at the national level, which leads to the direct or indirect discrimination and non-compliance with the principle of free competition.

\subsection{Specifics of main public procurement procedures}

Let us consider some aspects and peculiarities of separate stages (and their components) of the government/public procurement procedure in more detail. First of all, let us pay attention to the requirements for the tender documentation (since, the more clearly, understandably and exhaustively the customer realizes and formulates its terms, the more really it is to provide/obtain what is needed).

The question about the list of the tender documentation being submitted by candidates for the participation in government procurement in Ukraine is regulated by Article 22 of the Law of Ukraine No.922-VIII and the Order of the Ministry of Economic Development and Trade 'On Approval of the Sample Tender Documentation' No.680. But, the said regulatory acts enable the customers to expand the content of the tender documentation for their own needs, which may be the formal reason for rejecting an offer.

As concerns the selection of candidates or tender offers, on the one hand, international documents enshrine common approaches, and national regulatory legal acts contain the exhaustive list of cases, when subjective characteristics of a participant/qualification criteria (Article 16 of the Law of Ukraine No.922-VIII), or of a tender offer may lead to exclusion from the procurement procedure (Article 17). The grounds for the exclusion are interpreted narrowly, and their applying is subject to discretionary powers of the customers. On the other hand, the relevance of participants in government/public procurement, or submission of a tender offer can be assessed on the 
REVISTA DE LA UNIVERSIDAD DEL ZULIA. 3ª época. Año 12 N 32, 2021

Viktoriia Holubieva et al. // International experience on the improvement of national ... 460-485

DOI: http://dx.doi.org/10.46925//rdluz.32.27

basis of their economic, financial and technical possibilities, which are a rather blurred wording with a wide range of interpretations (Pappas, 2005: 37-38).

In the conclusion of a procurement contract on the basis of the criterion of the most economically advantageous tender offer (Article 28), it is necessary to clearly specify the criteria (for example: price, delivery terms/performance, current funds, profitability, quality, aesthetic and functional indicators, technical value, post-sales maintenance and technical support) for establishing the economic utility of tender offers in refusal documents, or in a contract, or in an accompanying sheet, and preferably, in order of decreasing or increasing the importance, which will force the customer to list the criteria he uses while evaluating tender offers, and will not enable to use other unidentified criteria (Pappas, 2005: 39). For example, in Indonesia 'calculations for the value of local content can include design, engineering, IPR, raw materials, facilities/infrastructure costs, education and training, labor costs, and after-sales service' (USA, 2017: 228). The similar practice is also taking place in the United Kingdom, when all participants in government procurement are informed, within the regulatory-determined time period, about its results (with relevant explanations), as well as undergo an 'interview' as for its passing/conducting.

In accordance with the Polish law, a tender offer is submitted in Polish; the exhaustive list of documents (and their form), which may be required from suppliers (Urząd Zamówień Publicznych, n.d.), must have a translation into Polish, if submitted in a different language. The similar rule that applies only to the customer is enshrined in Article 15 of the Law of Ukraine No.922-VIII: according to his decision, 'simultaneously all documents may have an authentic translation into another language', but 'the definitive text is the text set forth in the Ukrainian language'.

According to the OECD, the formation of a contract, starting from the determination of requirements for its concluding until its conclusion, is still the most regulated and transparent phase of the procurement cycle (OECD, 2009: 110).

Section VII of the Law of Ukraine 'On Public Procurement' is devoted to the procurement contract. In domestic practice, the invitation to the procedure and list of the tender documentation include a draft procurement contract with the mandatory indication of the order for chainging its conditions (Article 22:7). The said contract must correspond to the established standard forms, and in spite of everything, it remains unchanged, which, 
REVISTA DE LA UNIVERSIDAD DEL ZULIA. 3ª época. Año 12 N 32, 2021

Viktoriia Holubieva et al. // International experience on the improvement of national ... 460-485

DOI: http://dx.doi.org/10.46925//rdluz.32.27

in fact, is a violation of the principle of 'a free contract', as a participant-winner cannot actually change anything therein, either with negotiations, or without them. In this regard, for example, the experiences of Australia (one of the most advanced systems of typical/template government contracts (Australian Government, n.d.)), the United Kingdom (the contractual system of which contains over 450 standard contracts) and Turkey, are interesting. Turkey is not a signatory to the WTO Agreement on Government Procurement but has participated as an observer in the WTO Committee on Government Procurement since 1996. Turkish procurement law mandates the use of model contracts (i.e., standard forms), which many government procuring agencies refuse to modify (USA, 2017: 439).

It should separately be noted that the form of a public procurement contract under the Ukrainian law must be only written one, that is, the use of electronic signatures is not envisaged at all. In this issue, Ukraine has lagged far behind some of the world's countries, for example, the Republic of Korea has already moved from using the electronic digital signature to the system of Finger Recognition in E-Bidding System on the basis of the 'biometric safety marker', in order to improve the preservation of confidential information, its authenticity, as well as the ability of one individual to represent only one business entity.

In Ukraine, complaints about procurement contracts concluded are considered only in the court (Article 18:2 of the Law of Ukraine No.922-VIII). Summarizing the possibility for the judicial defense of interests of participants in the process of government/public procurement in Ukraine, the judicial reform as a whole continues to be relevant at the moment.

\section{Conclusions}

The process of public administration of public procurements in Ukraine is built on a contradiction: on the one hand, (de jure) the profile law determines a centralized type of implementation and regulation of public procurements, on the other hand, in practice (de facto) the public procurements process is organized according to a combined type. 
REVISTA DE LA UNIVERSIDAD DEL ZULIA. 3ª época. Año 12 N 32, 2021

Viktoriia Holubieva et al. // International experience on the improvement of national ... 460-485

DOI: http://dx.doi.org/10.46925//rdluz.32.27

For Ukraine, the creation of a special body to regulate and coordinate public procurement should be considered the optimal positive example of foreign countries (a close analog is the Central Public Procurement Agency in the Republic of Korea).

For a more successful operation of the Ukrainian informational system 'PROZORRO ' it is proposed to use foreign experience and introduce electronic databases and catalogs of a narrow direction (for example, thematic, subject) within the current system `PROZORRO`.

The unification of electronic public procurements systems remains to be a topical and unresolved task for the WTO GPA member countries. The experience of some countries in stimulating small and medium businesses in electronic public procurements is considered to be progressive and positive. We consider it necessary to adopt the experience of the countries of the USA, Israel, China and speed up the adoption of laws in Ukraine to support national commodity producers (for example, the Law of Ukraine 'Buy Ukrainian, pay Ukrainians').

To eliminate legislative deficiencies in regulating the procedure for tender proposals in Ukraine, it is proposed:

Firthly, to expand the notion of 'formal errors' (Article 22:3 of the Law of Ukraine 'On Public Procurement), for example, as for the absence (failure to specify by a candidate) of the information in a document (especially, in no particular form), if it is contained in the other tender documentation (for example, the phone number or e-mail address);

Secondly, to exclude documents, the informative value of which is doubtful, from the list of the tender documentation. For example: the purely formal approach to Article 22 of the Law of Ukraine 'On Public Procurement' in the matter of 'applying measures concerning the environmental protection', which is confirmed by the candidate's certificate in no particular form and is a formal transfer of responsibility from the customer in this issue;

Thirdly, to create a separate appendix with the exhaustive list of all necessary documents (in the understanding and at the discretion of the customer) regarding a specific tender offer, which will greatly simplify submitting an offer and verifying it by the Tender Committee. For example, Article 16 of the Law of Ukraine 'On Public Procurement' contains the list of the qualification criteria to be set by the customer. In particular: 
REVISTA DE LA UNIVERSIDAD DEL ZULIA. 3ª época. Año 12 N 32, 2021

Viktoriia Holubieva et al. // International experience on the improvement of national ... 460-485

DOI: http://dx.doi.org/10.46925//rdluz.32.27

'Availability of equipment and material and technical facilities' requires the customer not to ensure the formal specification ((something like the availability of the office equipment and furniture), especially that it is very difficult to determine its exclusive list), but to clearly understand, what sort of that base should be and by which documents it must be confirmed so that this fact does not create formal grounds for rejecting an offer;

'Availability of appropriately qualified employees with the necessary knowledge and experience', which is most often supported by copies of diplomas (or other documents), employment books or free-form certificates, but the education/qualification does not guarantee the ability to perform a certain type of the work, and the experience (positive or negative) of a separate employee does not mean that exactly he will be involved in the fulfillment of a government order. (By the way: in Japan, one of the main requirements for the participation in government procurement is the business reputation of a participant; and in Germany, it is exactly the availability of experience and skilled employees);

'The availability of the documented experience in the implementation of a similar contract': we note that the 'similarity' refers to the subject-matter of a contract precisely, and the real confirmation of the high-quality performance can be the reference of another consumer of the product/service, for whom such a contract was performed, which may be supported by a statement in no particular form on the performance, and/or a letterreference on the high-quality performance (in both cases, contact details must be indicated for the actual verification of their content). Separately, it should be noted for foreign participants that in fact, it is not allowed to require the mandatory presence of previously awarded/concluded contracts in the same country, but it is possible to require the presence of the previous experience, including abroad.

In order to avoid misleading participants in procurement, it would also be appropriate to clarify based on the legal framework (in Article 18:2:6 of the Law of Ukraine 'On Public Procurement') that the term for filing complaints against any conditions of the tender documentation should be calculated from the final date for the submission of tender offers, regardless of the fact, whether changes were made to it.

\section{References}

Atamanchuk, H. (2006). Theory of Public Administration. Moscow: Omeha-L. 
REVISTA DE LA UNIVERSIDAD DEL ZULIA. 3ª época. Año 12 N 32, 2021

Viktoriia Holubieva et al. // International experience on the improvement of national ... 460-485

DOI: http://dx.doi.org/10.46925//rdluz.32.27

Australian Government. (n.d.). AusTender. Official website. https://www.tenders.gov.au

BUSINESS.GOVT.NZ. (2020). Government Procurement of New Zealand. Official website. http://www.business.govt.nz

Buyandsell.gc.ca. (n.d.). Public Works and Government Services Canada. Official website of Government of Canada. https://buyandsell.gc.ca/for-businesses/selling-to-thegovernment-of-canada

Canada. (2015). Trade Commissioner Service. State and Local Government Opportunities.

Collins Dictionary (n.d.). Terms \& Conditions. HarperCollins, Glasgow. California. https:/www.collinsdictionary.com/dictionary/english/technology

EPLO. (n. d.). National School of Political Studies and Public Administration. Faculty of Public Administration. Thematic research reports. http://www.balcannet.eu/materiale/New\%20Technologies\%20in\%20the\%20service\%20of \%20efficient\%20public\%20\%20\%20\%20\%20\%20admini.pdf

EU. (2007). Commission Regulation EU. Amending Regulation (EC) No2195/2002 of the European Parliament and of the Council on the Common Procurement Vocabulary (CPV) and Directives 2004/17/EC and 2004/18/EC of the European Parliament and of the Council on public procurement procedures, as regards the revision of the CPV, No213/2008.

EU. (2019a). European Commission. Market Access Database. https://madb.europa.eu/madb/

EU. (2019b). Common Procurement Vocabulary (CPV).

EU-Ukraine. (2019). Integration within Association: Dynamics of the EU - Ukraine Agreement Implementation. Project 'Civic Synergy' of the International Renaissance Foundation. Kyiv.

FPDS. (n.d.). U.S. General Services Administration Federal Government computer system. Official website of the US Business Opportunities // https://beta.sam.gov/.

GETS.GOVT.NZ (n.d.). New Zealand Government Electronic Tenders Service (GETS). Official website. http://www.gets.govt.nz

IBRD. (1995). Purchases under the IBRD Loans and IDA Credits. Manual. (Guide for Procurement under the IBRD Loans and IDA Credits).

ISRAEL NATURAL GAS LINES LTD. (2020). Official website. http://www.ingl.co.il/?page_id=319\& $\&$ lang=en

Israeli Government Procurement Administration. (2020). Official website of Israeli Government Procurement // https://mr.gov.il/ilgstorefront/en

Ivanov, V. \& Patrushev, V. (1995). Social public administration technologies. N-Novhorod: Nizhnehorodskii gosuniversitet. 
REVISTA DE LA UNIVERSIDAD DEL ZULIA. 3ª época. Año 12 N 32, 2021

Viktoriia Holubieva et al. // International experience on the improvement of national ... 460-485

DOI: http://dx.doi.org/10.46925//rdluz.32.27

Ivanov, V. \& Patrushev, V. (2001). Innovative social technologies of state and municipal administration. Moscow: Economika.

Japan External Trade Organization (JETRO). (n.d.). Official website http://www.jetro.go.jp/en/database/procurement/

Nabiullin, V.Sh. \& Kuznetsova, I.V. (2012). International Experience of the Procurement Information Provision. Academic Supplement to the Journal "Government Order": Management, Placement, Provision, 7: 16-17.

NAICS Association. (2018). Official website of NAICS. http://naics.com/search/

NDP 'Alians Media'. (n.d.). Tender sites of the countries of the world. Information and reference catalog. http://vneshmarket.ru/content/document_r_CE548245-AlCA-43E9-A011F076E6CBlC85.html

New Zealand. (n.d.). Ministry of Business, Innovation and Employment. Official website. http://www.med.govt.nz

NTA (2020). Official website of NTA Metropolitan Mass Transit System Ltd. (2020. http://www.nta.co.il/en/tenders

OECD. (2009). OECD Principles for Integrity in Public Procurement.

OECD. (2015). Anti-Corruption Reforms in Ukraine. Round 3 Monitoring of the Istanbul AntiCorruption Action Plan of Mar. 24.

OECD. (2017). Anti-Corruption Reforms in Ukraine. Fourth Round of Monitoring of the Istanbul AntiCorruption Action Plan of Sept. 13.

Pappas, S. (2005). The EU Policy in Government Procurement. Kyiv: Taras Shevchenko National University of Kyiv, 2005.

Pokrovskaya, V.V. \& Uskova, Y.A. (2008). Modern Foreign Experience in the Field of the Government Procurement Development. Russian Foreign Economic Bulletin, 3(March): 33.

Pyvovar Yuriy, Detiuk Andriy, Mykolenko Oleksandr, Zapototska Olena, Lapka Oksana. (2019). Legal Support of the System of State Control in the Process of Educational Governmental Order. Amazonia Investiga, 8(20): 166-179.

QlikTech International AB. (2020). KPIs. https://bi.prozorro.org/sense/app/fba3f2f2-cf5540a0-a79f-b74f5ce947c2/sheet/HbXjQep/state/analysis\#view/pEh

Resolution of the Cabinet of Ministers of Ukraine. Matters of the Ministry of Economic Development and Trade dd. 20.08.2014 No.459. 
REVISTA DE LA UNIVERSIDAD DEL ZULIA. 3ª época. Año 12 N 32, 2021

Viktoriia Holubieva et al. // International experience on the improvement of national ... 460-485

DOI: http://dx.doi.org/10.46925//rdluz.32.27

Tender Electronics Daily. (2020). Supplement to the Official Journal' of the EU, dedicated to European public procurement. Official website of government procurement of the European Union. http://ted.europa.eu/TED/

UN. (2019). Central Product Classification (CPC). https:/unstats.un.org/unsd/classifications/Family/Detail/1073

UNCITRAL. (1995). The UNCITRAL Model Law on Procurement of Goods, Construction and Services with the Guide to its Enactment. New York: UN. https://www.un.org/ru/documents/decl_conv/conventions/pdf/ml-procure-r.pdf

Urząd Zamówień Publicznych. (n.d.). Official website. https://www.uzp.gov.pl/ezamowienia2/informacje

USA. (2017). Office of the United States Trade Representative. National Trade Estimate Report on Foreign Trade Barriers.

Verhovna Rada of Ukraine (VRU). (2017). Draft Law of Ukraine. Buy Ukrainian, pay to Ukrainians (on making amendments to some legislative acts of Ukraine with regard to promoting the development of the industrial production and small and medium business), No.7206.

Zakupki.Prom.ua. (2020). Win government and commercial tenders using the mobile app. https://zakupki.prom.ua/lp/registration?type $=0 \&$ title $=\%$ D0\%B4\%D0\%B5\%Dl\%80\%D0\%B 6\%D0\%BO\%D0\%B2\%D0\%BD\%Dl\%96+\%D0\%B7\%D0\%B0\%D0\%BA\%Dl\%83\%D0\%BF\%D 1\%96\%D0\%B2\%D0\%BB\%Dl\%96\&source_id=dz.goog.search.zakupivli.government.ad03.m ain\&gclid=Cj0KCQjw_r3nBRDxARIsAJljleFv8bBv5h_g7u7Dy094EoJqZUSsAfYl2znB4ZYVHSCDz9JsnebJBUaAoRlEALw_wcB\#screen_two 